\title{
Pengaruh Disiplin IImu Terhadap Kecenderungan Mahasiswa Dalam Mengakses Informasi Melalui Media Sosial Menggunakan Metode Chi Square
}

\author{
Retno Palupi ${ }^{1)}$; SM Santi Winarsih ${ }^{2)}$ \\ 1,2) Program Studi Teknik Informatika, Fakultas Teknik, Universitas Kristen Surakarta \\ 1)palupiretno748@gmail.com; 2)santiwinarsih10@gmail.com
}

\begin{abstract}
Social media becomes necessity that is always consumed by many levels of society to looking for such of information. Social media services provide many features that make users can enjoying seaching in cyberspace. All the level of society, all the level of social background and all the level of professions are very familiar with various social media. Social media services on gadgets have facilities to obtain information quickly and easily, such as Facebook, Instagram, YouTube and etc. This study examines the usage of smartphones to determine whether there is a significant effect of students from various disciplines on the tendency of students to access the information needed to support assignments or to find out the required data through social media. The Chi Square method is used as a testing method to determine the effect of disciplines on student tendencies in accessing information topics through social media. The data analysis gave the measurable results based on quantitative data and interesting information. The results showed that the influence of the field of study on students' Tendencies depend on intensity time in accessing social media.
\end{abstract}

Keywords: disciplines, information topics, social media, chi square method

\section{PENDAHULUAN}

Di era digital saat ini , handphone yang lebih tepat lagi smartphone menjadi kelengkapan setiap orang, menjadi kebutuhan pokok yang harus dimiliki hampir setiap orang sebagai media berkomunikasi dan mendapatkan informasi.

Perkembangan informasi sangat mudah dan cepat diketahui masyarakat begitu pula berbagai informasi sangat mudah untuk dicari dan dimiliki tanpa seseorang harus meninggalkan tempat dia sedang beraktifitas. Semua kemudahan di bidang telekomunikasi dan informasi yang dinikmati masyarakat ini adalah hasil perkembangan teknologi informasi yang berkembang sangat cepat. Pada kelompok pelajar atau mahasiswa pun kehadiran smartphone memberi kontribusi yang positif, hal ini tentu saja tidak lepas dari dampak negatifnya sangat banyak. Mahasiswa tidak dapat terlepas dari internet, berselancar di dunia maya menjadi kebutuhan yang saat ini sangat perlu dan mudah dilakukan. Jika ditinjau dari sisi positif, smartphone menjadi sahabat mahasiswa dalam belajar, bermain, berkomunikasi dan banyak lagi manfaat positif yang diambil. Pemanfaatan smartphone dengan segala layanan dan fitur yang ditawarkan menjadi topik menarik untuk mengamati kecenderungan mahasiswa dalam mengakses informasi yang dibutuhkan untuk mendukung tugas ataupun mengetahui datadata yang diperlukan sesuai dengan disiplin ilmu masing-masing. Mengacu dari penelitian sebelumnya ini memanfaatkan teori uses and gratifications untuk membahas tentang perilaku mahasiswa dalam memanfaatkan media sosial. Responden berasal dari 3 perguruan tinggi negeri di Kota Padang.

Instrumen penelitian yang digunakan adalah dengan metode angket dan wawancara kepada responden kemudian dilakukan pengolahan data statistik.

dan wawancara. Dari analisis yang dilakukan diperoleh informasi $97 \%$ mahasiswa mengaku sebagai pengguna aktif media sosial[1].

Perangkat teknologi informasi menjadi kebutuhan primer bagi hampir setiap orang karena kemudahan dan fasilitas yang ditawarkan dan hampir setiap orang memiliki perangkat tersebut, bahkan satu orang bisa memiliki perangkat teknologi informasi lebih dari satu. Pada saat ini untuk mendapatkan informasi secara cepat dan akurat orang tidak membutuhkan energi yang besar dan waktu yang lama. Banyak aplikasi media sosial yang bisa diakses dari perangkat tersebut ketika ada jaringan internet. Adanya media sosial sangat membantu terciptanya komunikasi dari 
berbagai tempat di penjuru dunia dalam waktu yang cepat dan mudah dan sangat mudah[2].

\section{TINJAUAN PUSTAKA}

\subsection{Tinjauan Teori}

Pemanfaatan teknologi informasi dan komunikasi dilakukan di semua kalangan masyarakat. Fasilitas yang disediakan oleh berbagai aplikasi yang dipasang/diinstal pada perangkat seperti smartphone, laptop, komputer PC dan perangkat digital lainnya memberi kemudahan dan pendukung berbagai aktifitas terutama bagi mahasiswa yang saat ini mengikuti perkuliahan daring, begitu juga bagi pengajar dan berbagai kelompok masyarakat yang bekerja secara daring[3]. Di masa pandemi ini masyarakat pada awalnya dipaksa untuk menyesuaikan dengan penggunaan teknologi informasi, namun seiring perjalanan waktu masyarakat menjadi lebih kreatif dan inovatif dalam memanfaatkan kemajuan teknologi.

Kebutuhan manusia untuk berinteraksi dan berkomunikasi sangat penting dalam melakukan berbagai proses dalam kehidupannya. Berbagai media sosial menjadi sarana yang memberi kontribusi terhadap kelancaran hubungan sosial. Walaupun dunia nyata dibatasi oleh protokol untuk melakukan social distancing namun di dunia maya arus komunikasi berjalan lancar dan tanpa batas walaupun jarak terpisah sangat jauh sekalipun. Masyarakat tetap bisa bertemu dan bersosialisasi karena adanya jaringan internet dan perangkat digital. Aplikasi-aplikasi media sosial menjadi sarana yang memungkinkan arus komunikasi berjalan baik untuk berbagai kalangan, bahkan arus komunikasi tersebut berjalan sangat cepat. Aplikasi WhatsApp, You Tube, Instagram, Facebook, dan aplikasi yang lain diminati oleh masyarakat luas. Di dalam pelaksanaannya selain memberi kontribusi yang baik dituntut perilaku pengguna media sosial yang bertanggungjawab terhadap diri sendiri dan pihak lain.

Pembelajaran daring di masa pandemi membutuhkan fasilitas media sosial. Berbagai aktivitas dilakukan untuk menyelenggarakan pembelajaran yang efektif dan memberi hasil yang maksimal. Perubahan metode pembelajaran ini mengubah juga pola dan metode mahasiswa dalam belajar. Makin meningkatnya teknologi informasi dan komunikasi mendorong animo masyarakat khususnya mahasiswa dalam memanfaatkan ketersediaan media sosial yang ada.

\subsection{Landasan Teori}

\subsubsection{Media Sosial}

Media sosial adalah media daring yang digunakan untuk kebutuhan komunikasi jarak jauh, proses interaksi antara user satu dengan user lain, serta mendapatkan sebuah informasi melalui perangkat aplikasi khusus menggunakan jaringan internet. Tujuan dari adanya social media sendiri adalah sebagai sarana komunikasi untuk menghubungkan antar pengguna dengan cakupan wilayah yang sangat luas. Agar pengguna media sosial (medsos) lebih mudah dan cepat, dibutuhkan koneksi internet.

Penggunaan media sosial dalam kehidupan mempengaruhi perilaku dan gaya hidup manusia. Ketersediaan berbagai fasilitas layanan / fitur di berbagai media sosial menimbulkan tuntutan masyarakat yang semakin besar terhadap kebutuhan jaringan internet. Jaringan internet yang disediakan berbagai penyedia jasa jaringan internet berlomba juga untuk memberi layanan jasa internet yang semakin baik kualitasnya[4].

Layanan media sosial yang banyak digunakan saat ini adalah Youtube, Facebook, Instagram selain WhatsApp. Berbagai fitur yang ditawarkan oleh media social tersebut sangat memberi kemudahan bagi masyarakat dalam mengakses informasi dan berkomunikasi.

\subsubsection{Pengguna Media Sosial}

Dari hasil penelitian diperoleh jumlah data pengguna media sosial untuk perempuan sebesar $56 \%$, untuk laki-laki sebesar $44 \%$. Jumlah ini juga memiliki rentang usia, umumnya mereka di rentang usia produktif, yaitu pada rentang 18-26 tahun. Laki-laki dan perempuan dalam penggunaan aplikasi media sosial juga tidak berbeda jauh, artinya keduanya memiliki kecenderungan yang sama dalam memilih jenis aplikasi yang dimiliki dan mereka pada umumnya memiliki beberapa aplikasi. Ditinjau dari pemakaian waktu dalam menggunakan media sosial baik laki-laki ataupun perempuan tidak terdapat perbedaan yang signifikan. Keduanya menggunakan waktu yang cukup banyak di dalam menggunakan media sosial dan berselancar di dunia maya. Bahkan sangat dimungkinkan dalam satu waktu yang sama digunakan beberapa aplikasi media sosial sekaligus yang saling dukung. Di kalangan mahasiswa kondisi ini sangat menguntungkan karena memberi kemudahan dalam menyelesaikan penugasan dan efisiensi waktu. Bagi yang bekerja adanya media sosial tetap 
memungkinkan komunikasi dan kemajuan informasi.

\section{Penggunaan Media Sosial di Kalangan Mahasiswa}

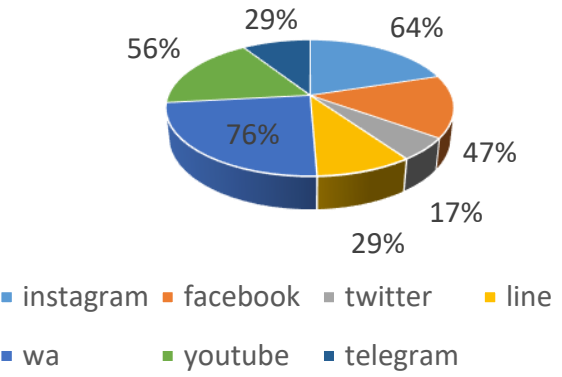
Gambar 1. Penggunaan Media Sosial di
Kalangan Mahasiswa

Para pelaku industri elektronik memberikan penawaran yang menarik di berbagai fitur perangkat digital yang dihasilkan. Berbagai jenis smartphone ditawarkan dengan layananlayanan menarik dan harga terjangkau[5].

\subsubsection{Perilaku Pengguna Teknologi Informasi}

Peran teknologi informasi yang memberi banyak keuntungan ini berkembang pesat dan sangat dibutuhkan karena perannya mampu mempermudah kinerja. Media sosial menjadi partner manusia sebagai sarana untuk saling berbagi, saling bertukar foto, data dan dokumen lainnya. Media sosial berperan sebagai sarana promosi pada berbagai produk/jasa yang dapat ditawarkan kepada pengguna media sosial tanpa harus mengeluarkan biaya yang besar tetapi dengan keuntungan yang berlipat ganda. Penggunaan media sosial juga dapat memberikan dampak negatif terhadap masyarakat, seperti yang kita lihat sekarang media sosial dijadikan media untuk menanamkan kebencian terhadap orang lain dengan mengunggah kata-kata atau gambar yang tidak etis sehingga terbangun rasa tidak senang dan benci terhadap seseorang. Teknologi informasi memberi manfaat yang baik dan maksimal ketika dipergunakan sesuai dengan fungsinya tetapi bisa sebaliknya ketika digunakan dengan tidak tepat, tidak sesuai dengan fungsinya. Perilaku masyarakat sebagai pengguna teknologi ini menentukan hasil dari penggunaan teknologi informasi tersebut, memberi manfaat yang baik dan berguna atau memberi dampak negatif dan merugikan.[6].

\subsubsection{Metode Chi- Square}

Metode Chi Square adalah salah satu jenis uji komparatif non parametris yang dilakukan pada dua variabel, di mana skala data kedua variabel adalah nominal atau ordinal. (Apabila dari 2 variabel, ada 1 variabel dengan skala nominal maka dilakukan uji chi square dengan merujuk bahwa harus digunakan uji pada derajat yang terendah)

Variabel yang digunakan dalam penelitian ini adalah variabel nominal atau ordinal. Analisa chi square diterapkan dengan melakukan hipotesis apakah apakah ada perbedaan yang signifikan antara frekuensi data yang diobservasi dengan frekuensi data yang diharapkan. Teknik analisis yang dilakukan adalah menguji adanya perbedaan antara frekuensi observasi (Oi) dengan frekuensi harapan $(\mathrm{Ei})$.

Ketentuan-ketentuan yang harus dipenuhi pada penggunaan chi square yaitu:

Frekuensi observasi (Oi) dalam cell tidak ada yang bernilai 0 (nol).

- Jika bentuk tabel 2 X 2, maka tidak boleh ada 1 cell pun yang memiliki frekuensi harapan kurang dari 5.

Jika bentuk tabel lebih dari $2 \times 2$, misalnya $2 \times 3$, maka jumlah cell dengan frekuensi harapan yang kurang dari 5 tidak boleh lebih dari $20 \%$.

Rumus Chi Square adalah:

$$
\chi^{2}=\sum_{i=0}^{n} \frac{(O i-E i)^{2}}{E i} \ldots \ldots \ldots \ldots
$$

$\chi^{2}=$ distribusi Chi Square

$\mathrm{O}_{\mathrm{i}}=$ frekuensi observasi pengamatan ke-i

$E_{i}=$ frekuensi harapan pengamatan ke-i

Derajat bebas (degree of freedom $=d f$ ) digunakan sebagai acuan dalam membandingkan nilai Chi Square tabel. Derajat bebas dirumuskan:

$d f=(b-1)(k-1)$

$\mathrm{b}=$ banyaknya baris

$\mathrm{k}$ = banyaknya kolom

Kesimpulan yang diambil dari analisis ini

dengan cara membandingkan $\chi^{2}$ hitung dengan $\chi^{2}$ tabel yaitu :

Bila $\chi^{2}$ hitung $\geq\left(\chi^{2}\right.$ tabel $)$ maka Hipotesis Nol $\left(\mathrm{H}_{0}\right)$ ditolak \& Hipotesis Alternatif $\left(\mathrm{H}_{\mathrm{a}}\right)$ diterima. 
- Bila $\chi^{2}$ hitung $<\chi^{2}$ tabel maka Hipotesis Nol $\left(\mathrm{H}_{0}\right)$ diterima \& Hipotesis Alternatif $\left(\mathrm{H}_{\mathrm{a}}\right)$ ditolak [7].

\section{METODE PENELITIAN}

Populasi adalah seluruh objek penelitian yang terdiri atas manusia, hewan, benda-benda, tumbuhan, peristiwa, sebagai sumber data yang mempunyai karakteristik tertentu dalam suatu penelitian yang dilakukan

Populasi penelitian ini adalah mahasiswa di Universitas Kristen Surakarta program studi Teknik Informatika mewakili bidang ilmu teknik, program studi Manajemen mewakili bidang ilmu sosial dan mahasiswa Sekolah Tinggi IImu Kesehatan Nasional Surakarta program studi Farmasi mewakili bidang ilmu kesehatan. Pengumpulan data dilakukan dengan membagikan angket pertanyaan yang menggunakan skala ordinal. Daftar pertanyaan yang diajukan terdiri dari: (1) keaktifan pengguna internet dan media social; (2) platfom media sosial yang saat ini digunakan dan yang paling sering digunakan;

(3) tujuan dan motivasi pengguna menggunakan media social; (4) alokasi waktu yang digunakan untuk mengakses media sosial. Jumlah sampel yang diambil 105 mahasiswa. adalah:

Metode yang dilakukan dalam penelitian ini

\section{Metode Pengumpulan Data}

Pada penelitian ini untuk pengambilan sampel menggunakan metode purposive sampling methods, yaitu mengambil sampel berdasarkan penilaian kriteria yaitu diambil dari mahasiswa berlatar belakang disiplin ilmu sosial, ilmu teknik dan ilmu kesehatan.

\section{Metode Pengolahan dan Analisa Data}

Pengolahan data menggunakan software Statistical Package for the Social Science (SPSS versi 23), menggunakan analisis data variabel kategorik yaitu analisis Chi Square.

\section{Metode Observasi dan Implementasi}

Observasi sampel dilakukan dengan memberikan angket kepada responden dari 2 perguruan tinggi di 3 program studi, setelah terpilih angket valid (tidak cacat, semua pertanyaan dijawab responden) dilakukan rekapitulasi dan pengolahan data menggunaan SPSS. Analisa data mengikuti langkah-langkah pengujian menggunakan analisis Chi square. Berdasarkan hipotesa yang ditetapkan di awal analisa maka ditarik kesimpulan berdasarkan perbandingan perhitungan dan tabel distribusi nilai Chi Square.

\section{Hasil Dan Pembahasan}

Observasi dilakukan terhadap 105 mahasiswa yang terdiri dari mahasiswa ilmu sosial teknologi dan ilmu kesehatan diperoleh rekapitulasi seperti pada Tabel 1 dan Tabel 2. Media sosial yang digunakan dalam pengambilan sampel adalah Youtube, Facebook, dan Instagram.

Tabel 1. Tabel Tabulasi Antara Bidang IImu Dengan Intensitas Mengakses Media Sosial

\begin{tabular}{|l|c|c|c|}
\hline \multirow{2}{*}{ Bidang IImu } & \multicolumn{3}{|c|}{ Intensitas Mengakses } \\
\cline { 2 - 4 } & Rendah & Sedang & Tinggi \\
\hline Sosial & 12 & 12 & 9 \\
\hline Teknik & 11 & 12 & 10 \\
\hline Kesehatan & 8 & 9 & 22 \\
\hline
\end{tabular}

Intensitas Rendah : < $5 \mathrm{jam} / \mathrm{hari}$;

Sedang $\quad: 5-10 \mathrm{jam} / \mathrm{hari}$

Tinggi $: \geq 10 \mathrm{jam} /$ hari

Tabel 2. Tabel Tabulasi Antara Bidang Ilmu Dengan Jenis Media Sosial

\begin{tabular}{|l|c|c|c|}
\hline \multirow{2}{*}{ Bidang IImu } & \multicolumn{3}{|c|}{ Media Sosial } \\
\cline { 2 - 4 } & Youtube & FB & IG \\
\hline Sosial & 13 & 11 & 12 \\
\hline Teknik & 9 & 10 & 9 \\
\hline Kesehatan & 10 & 13 & 18 \\
\hline
\end{tabular}

Analisa antara bidang ilmu dan intensitas mengakses media sosial sebagai berikut:

Langkah 1: Membuat hipotesa

$\mathrm{Ha}$ : Ada hubungan antara bidang ilmu dengan intensitas akses

Ho :Tidak ada hubungan antara bidang ilmu dengan intensitas akses

Langkah 2: Menghitung nilai Chi Square Diperoleh hasil olah data menggunakan SPSS seperti tampak pada Tabel 3.

Tabel 3. Tabel Nilai Chi Square 1

\begin{tabular}{|l|r|r|r|}
\hline & Value & df & \multicolumn{1}{|c|}{$\begin{array}{c}\text { Asymptotic } \\
\text { Significance (2- } \\
\text { sided) }\end{array}$} \\
\hline $\begin{array}{l}\text { Pearson Chi- } \\
\text { Square } \\
\text { Likelihood Ratio }\end{array}$ & $7.964^{\mathrm{a}}$ & 4 & .093 \\
$\begin{array}{l}\text { Linear-by-Linear } \\
\begin{array}{l}\text { Association } \\
\text { Nof Valid } \\
\text { Cases }\end{array}\end{array}$ & 5.513 & 1 & .094 \\
\hline
\end{tabular}


a. 0 cells $(0.0 \%)$ have expected count less than 5 . The minimum expected count is 9.74 .

Langkah 3. Kaidah Pengujian

Dari hitungan diperoleh :

$\chi^{2}$ hitung $=7.964>\chi^{2}$ tabel $=5,591$

Karena $\chi^{2}$ hitung $>\chi^{2}$ tabel maka Ho ditolak jadi ada hubungan antara bidang ilmu dengan intensitas akses.

Mahasiswa dari bidang ilmu kesehatan memiliki peringkat tertinggi dalam intensitas akses media sosial, sedangkan mahasiswa dari bidang ilmu sosial dan teknik memiliki intensitas waktu yang hampir sama dalam mengakses media sosial.

Analisa antara bidang ilmu dan jenis media sosial yang digunakan sebagai berikut:

Langkah 1 : Membuat hipotesa

$\mathrm{Ha}$ : Ada hubungan antara bidang ilmu dengan jenis media sosial

Ho : Tidak ada hubungan yang signifikan antara antara bidang ilmu dengan jenis media sosial

Langkah 2 : Menghitung nilai Chi Square Diperoleh hasil olah data menggunakan SPSS ditunjukkan pada Tabel 5.

Tabel 5. Tabel Nilai Chi Square 2

\begin{tabular}{|l|r|r|r|}
\hline & Value & Df & \multicolumn{1}{|c|}{$\begin{array}{c}\text { Asymptotic } \\
\text { Significance (2- } \\
\text { sided) }\end{array}$} \\
\hline $\begin{array}{l}\text { Pearson Chi- } \\
\text { Square }\end{array}$ & $6.138^{\mathrm{a}}$ & 4 & .189 \\
$\begin{array}{l}\text { Likelihood } \\
\text { Ratio } \\
\text { Linear-by- } \\
\text { Linear } \\
\begin{array}{l}\text { Association } \\
\text { N of Valid } \\
\text { Cases }\end{array}\end{array}$ & 6.155 & 4 & .188 \\
\hline
\end{tabular}

0 cells $(0.0 \%)$ have expected count less than 5 .

The minimum expected count is 7.73 .

Dari hitungan diperoleh

$\chi^{2}$ hitung $=6.138>\chi^{2}$ tabel $=5,591$

Karena $\chi^{2}$ hitung $>\chi^{2}$ tabel maka Ho ditolak

jadi ada hubungan yang signifikan antara ilmu dengan jenis media sosial yang diakses. Mahasiswa dari bidang ilmu sosial cenderung memanfaatkan media sosial Youtube untuk mengakses informasi, mahasiswa bidang ilmu teknik menggunakan Youtube, Facebook dan Instagram hampir sama persentasenya, untuk mahasiswa dari bidang ilmu kesehatan lebih menyukai Instagram dalam menggunakan media sosial.

Pemanfaatan media sosial oleh mahasiswa yaitu untuk: (1) alat komunikasi (telepon/ chat); (2) mencari informasi; (3) interaksi sosial / pertemanan;(4) bisnis online; (5) update status (posting foto/ video/ informasi); (6) hiburan/ relaksasi (mendengarkan musik/ menonton video); (7) mengisi waktu luang.

Diagram perbandingan hubungan antara bidang ilmu dengan intensitas mengakses dan pengujian antara bidang ilmu dan jenis media sosial yang diakses adalah sebagai berikut:

Tabel 4. Tabel Hasil Crosstabullation Bidang IImu dan Jenis Media Sosial

\begin{tabular}{|ll|r|r|r|r|}
\hline & & \multicolumn{3}{|c|}{ MedSos } & \\
\cline { 3 - 5 } & & $\begin{array}{c}\text { You } \\
\text { tube }\end{array}$ & \multicolumn{1}{|c|}{ FB } & \multicolumn{1}{|c|}{ IG } & Total \\
\hline Bidang & S & 13 & 11 & 12 & 36 \\
Ilmu & $\mathrm{T}$ & 9 & 10 & 10 & 29 \\
& $\mathrm{~K}$ & 10 & 7 & 23 & 40 \\
Total & & 32 & 28 & 45 & 105 \\
& & & & & \\
\hline
\end{tabular}

Hubungan Bidang IImu Dengan Intensitas Akses Media Sosial

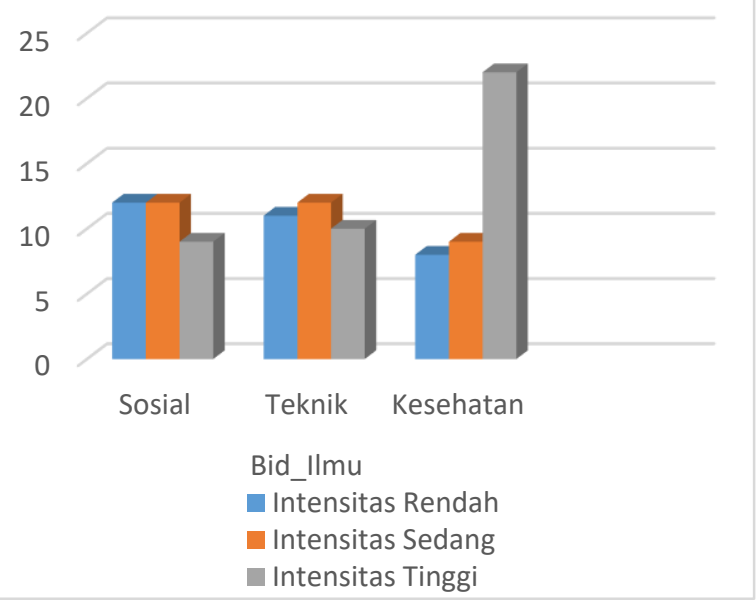

Gambar 2. Hubungan Bidang IImu dan Intensitas Akses Media Sosial 


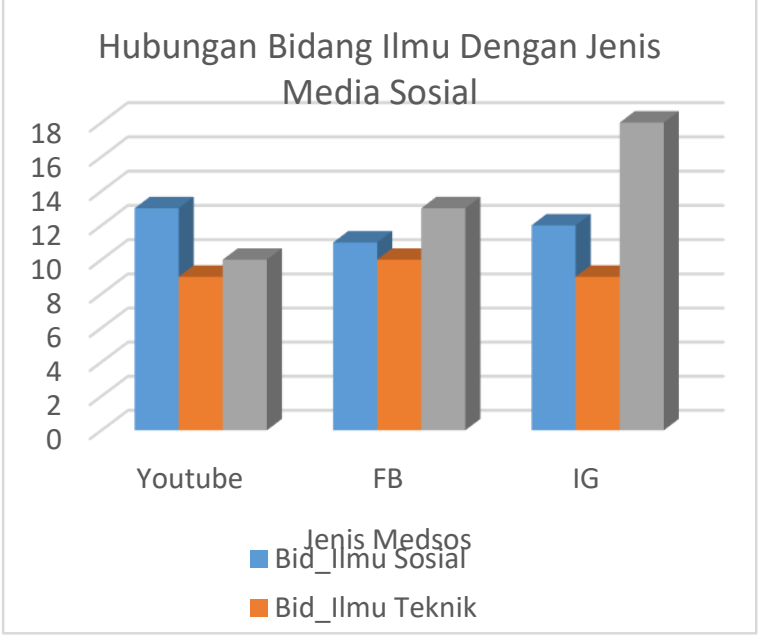

\section{Gambar 3. Hubungan Bidang IImu dan Jenis Media Sosial}

\section{PENUTUP}

\subsection{Kesimpulan}

Bidang ilmu dari mahasiswa mempengaruhi intensitas /banyak waktu yang digunakan dalam mengakses media sosial, baik itu mahasiswa bidang ilmu sosial, teknik maupun ilmu kesehatan. Mahasiswa dari bidang ilmu kesehatan memiliki peringkat tertinggi dalam intensitas akses media sosial, sedangkan mahasiswa dari bidang ilmu sosial dan teknik memiliki intensitas waktu yang hampir sama dalam mengakses media sosial.

Bidang ilmu dari mahasiswa mempengaruhi jenis media sosial yang digunakan mahasiswa dalam mengakses media sosial. Mahasiswa bidang ilmu sosial memanfaatkan Youtube untuk mengakses informasi, mahasiswa ilmu teknik menggunakan Youtube, Facebook dan Instagram hampir sama persentasenya, untuk mahasiswa dari bidang ilmu kesehatan lebih menyukai Instagram dalam menggunakan media sosial.

\subsection{Saran}

Penelitian ini bisa dikembangkan lagi untuk melakukan analisa perbandingan menggunakan media sosial bagi mahasiswi dan mahasiswa, perbandingan platform yang digunakan dalam menggunakan media sosial, perbandingan tujuan dan motivasi menggunakan media sosial.

\section{DAFTAR PUSTAKA}

[1] A. Saputra, "Survei Penggunaan Media Sosial Di Kalangan Mahasiswa Kota Padang Menggunakan Teori Uses and Gratifications," Baca J. Dokumentasi Dan Inf., vol. 40, no. 2, p. 207, 2019, doi:

\subsection{3/j.baca.v40i2.476.}

[2] S. Fitri, "Dampak Positif Dan Negatif Sosial Media Terhadap Perubahan Sosial Anak," Nat. J. Kaji. Penelit. Pendidik. dan Pembelajaran, vol. 1, no. 2, pp. 118-123, 2017, doi: 10.35568/naturalistic.v1i2.5.

[3] R. Komalasari, "Manfaat Teknologi Informasi Dan Komunikasi Di Masa Pandemi Covid 19," 2020. doi: 10.38204/TEMATIK.V7I1.369.

[4] Haryanto , "Pemanfaatan Media Sosial Sebagai Media Komunikasi Komunitas Pustakawan Homogen Dalam Rangka Pemanfaatan Bersama Koleksi Antar Perguruan Tinggi," Edulib, vol. 5, no. 1, pp. 83-89, 2016, doi: 10.17509/edulib.v5i1.2305.

[5] S. F. Soliha, "Tingkat Ketergantungan Pengguna Media Sosial Dan Kecemasan Sosial," Interak. J. IImu Komun., vol. 4, no. 1 , pp. 1-10, 2015, doi: 10.14710/interaksi.4.1.1-10.

[6] Rohma F. Doni, "Perilaku Penggunaan Smartphone Pada Kalangan Remaja," J. Speed Sentra Penelit. Eng. dan Edukasi, vol. 9, no. 2, pp. 16-23, 2017.

[7] V. W. Sujarweni, SPSS untuk Penelitian. 2014. Pustaka Baru Press. 